\title{
Psychometric Properties of the Life Orientation Test (LOT-R) for Sport
}

\section{Propiedades Psicométricas del Life Orientation Test (LOT-R) para el Deporte}

\section{Propriedades Psicométricas do Life Orientation Test (LOT-R) para o Esporte}

\author{
Angelo, D. L. ${ }^{1}$, Bido D. ${ }^{2}$, Corrêa, M. ${ }^{1}$, Hupfer B. ${ }^{1}$, Brandão R. F. ${ }^{1}$ \\ ${ }^{1}$ Post-Graduate Programme in Physical Education, University São Judas Tadeu, São Paulo, SP, Brazil, \\ ${ }^{2}$ Center for Social and Applied Sciences, University Presbyterian Mackenzie, São Paulo, SP, Brazil.
}

\begin{abstract}
The main objective of this research was to culturally adapt and evaluate the psychometric properties of the Life Orientation Test Revised version for the Brazilian sports context (LOT-R). The sample consisted of 953 young Brazilian athletes of both sexes, with a mean age of 16 years. The results of the confirmatory factor analysis produced two correlated dimensions, reflecting optimism and pessimism, and provided support for a two-factor model. A satisfactory fit was found for LOT-R for sport (LOT-R-Sport) with six items $(\chi 2=4.541$, df $=8$; CFI=1; $\mathrm{TLI}=1 ; \mathrm{RMSEA}=0$ [90\%IC $=0.000-0.024]$; SRMR=0.016). Satisfactory tests of internal consistency were also generated through the analysis of factor loadings. The Composite Reliability indices $(0.72 / 0.70)$ were suitable for Optimism and Pessimism, respectively. Motivation, Resilience and Satisfaction with Life showed positive correlations with Optimism and negative correlations with Pessimism, indicative of convergent validity. The configural, metric and scalar invariance was achieved, indicating that the LOT-R-Sport can measure athletes of different sexes, sports, ages and years of experience equally. Although more studies are needed to confirm the psychometric properties of the instrument, the adaptation of the LOT-R-Sport was the first step in the future works about the influence of Optimism on sports performance.
\end{abstract}

Keywords: optimism; pessimism; dimensionality; validation study.

RESUMEN: El objetivo principal de esta investigación fue adaptar y evaluar culturalmente las propiedades psicométricas de la versión brasileira del Life Orientation Test Revised para el contexto deportivo (LOT-R). La muestra consistió en 953 jóvenes atletas brasileños de ambos sexos, con una edad media de 16 años. Los resultados del análisis factorial confirmatorio produjeron dos dimensiones correlacionadas, que reflejan optimismo y pesimismo, y brindaron apoyo para un modelo de dos factores. Se encontró un ajuste satisfactorio para LOT-R con

Correspondence to: Daniela Lopes Angelo. Post-Graduate Programme in Physical Education University São Judas Tadeu. Email:

danialoppes@yahoo.com.br 


\section{Psychometric Properties of the LOT-R for Sport}

6 ítems $(\chi 2=4.541, \mathrm{df}=8 ; \mathrm{CFI}=1 ; \mathrm{TLI}=1 ; \mathrm{RMSEA}=0$ [90\% IC $=0.000-0.024]$; SRMR=0.016). También se generaron pruebas satisfactorias de consistencia interna a través del análisis de cargas factoriales. La Fiabilidad Compuesta (.72/ .70) fue adecuada en las variables latentes Optimismo y Pesimismo, respectivamente. Motivación, Resiliencia y Satisfacción con la Vida mostraron correlaciones positivas con Optimismo y correlaciones negativas con Pesimismo, indicativo de validez convergente. Se logró la invariancia configuracional, métrica y escalar, lo que indica que LOT-R-Sport puede medir atletas de diferentes sexos, deportes, edades y años de experiencia por igual. Aunque se necesitan más estudios para confirmar las propiedades psicométricas del instrumento, la adaptación de LOT-R al contexto deportivo fue el primer paso en el futuro sobre la influencia del Optimismo en el rendimiento deportivo.

Palabras clave: optimismo; pesimismo; dimensionalidad; estudio de validación.

RESUMO: O principal objetivo desta pesquisa foi adaptar culturalmente e avaliar as propriedades psicométricas da Life Orientation Test Revisada para o contexto esportivo (LOT-R). A amostra foi composta por 953 jovens atletas brasileiros de ambos os sexos, com idade média de 16 anos. Os resultados da análise fatorial confirmatória produziram duas dimensões correlacionadas, refletindo otimismo e pessimismo e forneceram suporte para um modelo de dois fatores. Foi encontrado um ajuste satisfatório para LOT-R para o esporte (LOT-R-Sport) com seis itens ítems $(\chi 2=4.541, \mathrm{df}=8 ; \mathrm{CFI}=1 ; \mathrm{TLI}=1 ; \mathrm{RMSEA}=0$ [90\% IC $=0.000-0.024]$; SRMR=0.016). Testes satisfatórios de consistência interna foram gerados através da análise de cargas fatoriais. Os índices Confiabilidade Composta (0.72/ 0.70) foram adequados para Otimismo e Pessimismo, respectivamente. Motivação, Resiliência e Satisfação com a Vida apresentaram correlações positivas com Otimismo e negativas com Pessimismo, indicativo de validade convergente. A invariância configural, métrica e escalar foi alcançada, indicando que o LOT-R-Sport pode avaliar de diferentes sexos, modalidades, idades e anos de experiência igualmente. Embora sejam necessários mais estudos para confirmar as propriedades psicométricas do instrumento, a adaptação do LOT-R-Sport ao contexto esportivo foi o primeiro passo para futuros estudos sobre a influência do otimismo no desempenho esportivo.

Palavras-chave: otimismo; pessimismo; dimensionalidade; estudo de validação.

\section{INTRODUCTION}

Optimism is a personality trait related to positive expectations regarding future events. Optimists are people who expect that good things will happen to them, while pessimists expect bad things to happen (Scheier, Carver, 1985). Dispositional optimism has been appointed as an important variable that must be studied in order to understand the psychological characteristics associated with peak performances (Naveira \& Morales, 2010).

In addition to being a personality characteristic of high-level athletes, the optimism has been associated with the expectancy for good outcomes, adaptive coping mechanisms (Öcal, Aygar, Atay, Ozturk, Onsuz \& Metintas, 2017) and less burnout (Hinz, Sander, Glaesmer, Brähler, Zenger, Hilbert \& Kocalevent, 2017). Empirical evidence shows the importance of optimism in the sports context as it is positively related to self-confidence, resilience and emotional adjustment during sports competition (García, Vallarino \& Montero, 2014). While optimism is also positively related to desirable behaviors, pessimism, on the other hand, is related to non-adaptive coping mechanisms, such as denial and avoidance (Hinz et al., 2017). Pessimistic athletes perform worse because they overestimate their negative experience (Juarros, Valle, González, Rosado \& Rosa, 2018).

Carver and Scheier (2014) anchored the definition of optimism and pessimism on expectations for the future expressed in models of motivation underlying behavior. The expectation is the conviction or uncertainty about the achievement of a goal. Efforts will be made towards the goal only if the person is confident enough about the expected results. Many 


\section{Angelo et al.}

studies indicate that optimism can be a good predictor of success for athletes, because when they have good expectations, they increase their efforts (Ortín, Rodríguez, García, de los Fayos \& González, 2018). Although there is a positive relationship between sports and levels of optimism, in Brazil, few studies have evaluated the construct in the sport context. The few studies that evaluated optimism in athletes had many methodological limitations (Bastianello, Pacico, $\&$ Hutz, 2014). Since optimism is a latent construct, good measurement tools are essential to capture the cultural diversity that exists in the country's sporting context.

One of the most used tools to measure dispositional optimism is the Life Orientation Test (LOT - Scheier \& Carver, 1985), but criticisms were made that the effects attributed to optimism were indistinguishable from neuroticism (Vallarino \& García, 2019). Another criticism was made regarding unidimensionality. The scale was originally designed as a one-dimensional instrument, but in some studies, confirmatory factor analysis generated significantly better-fit indices for the 2-factor - optimism and pessimism (Ribeiro, Pedro \& Marques, 2012; Appaneal, 2012; Hinz et al., 2017). Thus, a reviewed version (LOT-R; Scheier, Carver \& Bridges, 1994) was published. The items included in the LOT-R measure positive and negative expectations strongly linked to the future and are written in such a way that they are evaluated in many situations, and this guarantees a close correspondence between concepts when measured in different contexts.

The structure of LOT-R is consistent with the accumulation of evidence outside the science of sport and exercise. The version validated by Bastianello, Pacico and Hutz (2014) presented appropriate psychometric characteristics for use in the Brazilian population, however, global assessment may include content irrelevance related to sport outcomes. Once they are using an instrument that can be applied to multiple areas of life, like work, social life, etc., researchers usually instruct participants to focus on sports when answering the questions (for example, "regarding your participation in sports..."). Sometimes the question can be adapted to focus on sports (for example, substituting "my life" for "my sport activity"). Adapting the instrument this way is a common strategy when doing a research, because it can ensure a closer match between concepts when they are used in different fields. However, it is not known whether all items are appropriate or easily interpretable in the context of sport or whether the instrument captures optimism completely. This is because the instrument was not developed specifically for the sport. Adapting the scale to the sporting context would be an important step toward continued examination of this instrument and future work on the influence of optimism (versus pessimism) on sport and exercise behaviour (Appaneal, 2012).

The optimism is partly learned from past experiences of success and failure (Scheier, Carver \& Bridges, 1994) and can be developed, although more study is needed to indicate which variables facilitate it (Naveira \& Morales, 2010). The roots of optimism and pessimism are theoretical and empirical studies on the motivations expressed in human behavior. It is logical to think that people seek to commit their efforts to achieve the goals that they consider important. Efforts will be made towards the goal only if a person is motivated about the expected results (Carver \& Scheier, 2014). A study of subjective well-being observed that happy people had consistent trait optimism (Bastianello, Pacico, \& Hutz, 2014). (Gustems, Calderón and Santacana (2016) showed that subjective well-being and optimism are closely linked. These data corroborate the idea that positive feelings contribute to people having a greater sense of confidence about positive future events. Thus, an optimistic orientation is closely related to motivation and well-being. Resilience is another variable closely related to optimism. The association between these two variables act as a protector against the possibility of burnout (Reche et al., 2014).

The propose this paper is offer a valid and reliable psychometric instrument, short and easy-tounderstand and specifically developed for sports settings, so that researchers, coaches and sports psychologists can use it among young Brazilian athletes, in order to help understand better how optimism relates to psychological processes that contribute to achieving better performance in sport (Vallarino \& García, 2019). Thus, the aims of this study were: to culturally adapt the LOT-R-Sport to the Brazilian Portuguese version; to be focused on a specific aspect of the sport, which is the athlete's performance; to analyse the dimensionality and the 


\section{Psychometric Properties of the LOT-R for Sport}

psychometric properties of this new version; to test the invariance of the resulting model in gender and finally, to test the convergent validity of the LOT-R-Sport by the correlations between this scale and instruments commonly used to assess aspects related to performance in sport.

\section{METHOD}

The psychometric properties of the Brazilian version of the LOT-R-Sport were tested, following the procedures adopted by the authors of the original study. This study has a cultural adaptation and a deeper analysis of its structure is predicted using confirmatory factorial analysis, evidences of the construct validity and internal reliability for a sample of teenager athletes.

\section{Participants}

All athletes in this study are engaged in some type of competition (inter-club, municipal or state). A total of 953 athletes (483 girls and 470 boys) with an average age of 15.8 years $(\mathrm{SD}=.8)$, who are practitioners of the following sports: football $(\mathrm{n}=490)$, futsal $(\mathrm{n}=37)$, basketball $(\mathrm{n}=121)$, athletics $(\mathrm{n}=27)$, volleyball $(\mathrm{n}=$ $98)$ handball $(\mathrm{n}=158)$, rugby $(\mathrm{n}=54)$, hockey $(\mathrm{n}=$ 17), judo $(\mathrm{n}=54)$, karate $(\mathrm{n}=20)$, tae-kwon-do $(\mathrm{n}=$ 18 ) boxing $(n=11)$, cycling $(n=7)$, tennis $(n=37)$, swimming $(\mathrm{n}=54)$, artistic gymnastics $(\mathrm{n}=3)$, rhythmic gymnastics $(\mathrm{n}=38)$, and BMX $(\mathrm{n}=9)$ were recruited from 5 different sports clubs in São Paulo and evaluated in the period between May and December 2019. The athletes had an average of 2.8 training hours per day $(\mathrm{SD}=1.1), 4$ days per week (SD $=1.0$ ), and had 6 years of experience in the sport (SD $=3.1$ ). Those who did not agree to sign the consent form to participate in the study were excluded $(\mathrm{N}=9)$. This is a representative sample of the population of young athletes from São Paulo (sample size power = $0.95)$.

\section{Measures}

The LOT-R (Scheier, Carver \& Bridges, 1994) is composed by 10 items in total, but four of them are only fillers (statements that are included to hide the test's actual objective), and only 6 of them were designed to measure the dispositional optimism. Three items measure optimism and three items measure pessimism. Participants were asked to indicate how much they agree with the items using a Likert 7-point scale in which 1 means "I totally disagree" and 7 means "I totally agree". To obtain the total score, the items regarding pessimism are inverted and added to the score of the ones regarding optimism. Higher scores indicating greater optimism, and lower scores indicating lower optimism (or pessimism).

Diener, Emmons, Larsen and Griffin (1985) developed the Satisfaction With Life Scale (SWL) to measure globally how a person perceives well-being according to their own subjective criteria. In this instrument, athletes who indicate their degree of agreement with each of the 5 items on the scale using a 7-point Likert scale, ranging from 1 (Do not at all agree) to 7 (Totally agree). The Brazilian version validated by Gouveia, Milfont, Fonseca \& Coelho (2009) showed good internal consistency $(\alpha=0.81)$. For the data set of this study, the instrument presented goodness-of-fit indexes $(\chi 2=5.678, \mathrm{df}=5$; $\mathrm{CFI}=0.99$; TLI=0.99; RMSEA $=0.012(90 \% \mathrm{IC}=0.000-0.048)$; $\mathrm{SRMR}=0.027$ ).

Brief Resilience Scale (BRS - Smith et. al., 2008) was used to assess the participants' resilience (ability to recover from adversity). The Brazilian version of the scale (Neves, Barbosa, Silva, Brandão, \& Zanetti, 2018) includes six items, in which the participants were asked to indicate the extent to which the statements correspond to their current personal situation using a 5-point Likert scale, ranging from 1 (Do not at all agree) to 5 (Totally agree). The scale demonstrated good internal consistency $(\alpha=.72)$. For the data set of this study, the instrument presented goodness-of-fit indexes $(\chi 2=32.235, \mathrm{df}=9$; $\mathrm{CFI}=0.98$; TLI $=0.97$; RMSEA $=0.052(90 \% \mathrm{IC}=0.033-0.072)$; $\mathrm{SRMR}=0.069$ ).

Autonomous Motivation and Non Motivation was assessed using the Sport Motivation Scale (SMSII - Sport Motivation Scale-II), developed by Pelletier, Rocchi, Vallerand, Deci \& Ryan (2013). The Brazilian version (Nascimento Junior, Vissoci, Balbim, Moreira, Pelletier \& Vieira, 2014) of the Autonomous Motivation subscale includes 9 items, Non Motivation subscale includes 3 items in which the participants were asked to indicate the extent to which the statements correspond to their current personal situation using a 7-point Likert scale, ranging from 1 (Do not at all agree) to 7 (Totally agree). The scale demonstrated good internal consistency $(\alpha=.78)$. For the data set of this study, the instrument presented 


\section{Angelo et al.}

goodness-of-fit indexes $\quad(\chi 2=166.975, \quad \mathrm{df}=53$; $\mathrm{CFI}=0.98 ; \mathrm{TLI}=0.97 ; \mathrm{RMSEA}=0.048(90 \% \mathrm{IC}=0.040$ - 0.056); SRMR=0.058).

\section{Procedures}

Permission was requested for author of the original instrument, for a translation, adaptation and validation of the LOT-R-Sport for the Brazilian athletes. After the author's authorization, the process of translation and cross-cultural adaptation started. The translation followed the cross-cultural adaptations of instruments and measures on health science guidelines (Beaton, Bombardier, Guillemin \& Ferraz, 2000), which consists of seven steps: (1) translating the instrument from English to Portuguese language by two Brazilian professionals, generating $\mathrm{T} 1$ and $\mathrm{T} 2$ versions of the instrument; (2), synthesizing the two versions to design a new one, known as T3; (3) a back translation of the T3 version made by two English native speakers, generating the versions known as T4 and T5; (4) synthesizing those two versions to design a new one, known as T6; (5), the review of that version by two specialists on the field, what leads to the design of a new version, known as T7; (6), sending the T7 version to the author of the original study, so he could give his opinion as a specialist; (7) preparing the version known as $\mathrm{T} 8$.

The next step was to adapt the instrument to be focused on that context. The items should be adapted to present simplicity, clarity, relevance, and accuracy in relation to the evaluated factors. In order to do so, we consulted materials derived from the experience of the researchers in the sports context, the literature of the area, as well as other instruments used in the evaluation of athletes with interface with the construct. The version in which the items were adapted (for example, the statement "I have great expectancies, even when hard situations arise" was adapted for "During competitions, I have great expectancies, even when hard situations arise") was sent to four athletes who were already familiar with the construct, so they could express their opinion about the content and they could also make some suggestions for adjustments/ reformulations. It was not necessary to make any changes.

The pre-test version was presented to six participants (three boys and three girls), between the ages of 15 and 16, recruited from the athletes. Each participant answered the questions using the scale, and, later, they were interviewed to verify their understanding of the items and the instructions correctly, and also the suitability and the congruence between the expected answer and the one given. According to that process, there was no need to review the test, so the version of the LOT-R for Sports (LOTR-Sports) was complete, and we could start data collection.

This study was approved by the São Judas Tadeu University's Research Ethics Committee (69496017.1.0000.0089/2017). The researches went to sports clubs to invite athletes to participate in the study. Athletes and parents were informed about the nature of the study and signed the consent form. The date and time for the application of the questionnaire was scheduled. On that day, the participants were oriented about the procedures adopted in the study, and the importance of being honest when answering the questions. If any participant felt uncomfortable, they could interrupt his or her participation at any time. Then, the questionnaire was applied in the sport club, under the guidance of a researcher.

\section{Data Analysis}

The model were estimated with lavaan (Rosseel, 2012), from polychoric correlation matrices using robust weight least square (WLSMV) estimation, which has been found to outperform Maximum Likelihood with ordered-categorical items involving 5 or less answer categories (Ramírez, Holgado-Tello, García, \& Mendez, 2015). The adjustment indices

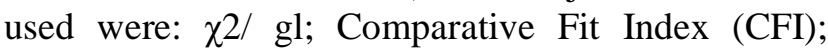
Tucker-Lewis Index (TLI); Standardized Root Mean Residual (SRMR) and Root Mean Square Error of Approximation (RMSEA). The $\chi 2$ / gl ratio must be < than 5 or, preferably, < than 3; CFI and TLI values must be > than 0.90 and, preferably above 0.95 ; RMSEA and SRMR values should be $<0.08$ or, preferably $<0.06$, with a confidence interval (upper limit $)<0.10$ (Brown, 2015). The evidence of validity based on the internal structure was measured through the Composite Reliability (CR $\geq 0.7$ ) (Bagozzi \& Yi, 1988; Hair, Babin \& Krey, 2017). For Evidence of validity based on external measures was evaluated Spearman's correlations between the LOT-R-Sport and related measures. 


\section{Psychometric Properties of the LOT-R for Sport}

A Multigroup Confirmatory Factor Analysis (MGCFA) was used to determine if the LOT-R-Sport configuration and parameters are invariant for different sexes (boys and girls), sports (team and individual), ages (14, 15, 16 and 17 years) and years of experience (from 0 to 3 years, from 4 to 6 years, and more than 6 years). This analysis is important because the differences between groups may be related to the usage of non-equivalent parameters of the instrument (Hirschfeld \& Brachel, 2014). The models evaluated were: Model 1 (configural invariance) analysed whether the structure of the scale was plausible for both groups; Model 2 (metric invariance) investigated if factor loadings of the items were equal across groups; Model 3 (scalar invariance) assessed whether the initial level of the latent variable was equal across groups (Brown, 2015). The models were ordered hierarchically. Each constrained model was nested within a less restricted one. The measurement invariance was assessed using the CFI difference test ( $\triangle \mathrm{CFI}$, Cheung \& Rensvold, 2002). If, when setting a parameter, a significant reduction is found in the CFI indexes $(\triangle \mathrm{CFI}>0.01)$, the measurement invariance cannot be accepted (Cheung \& Rensvold, 2002).

There was no missing value in dataset and data were analysed by using R Statistical Software 3.4.5 (R Core team, 2018) with Tidyverse (Wickham, 2017),
Lavaan (Rosseel, 2012), SemPlot (Epskamp, 2017), MVN (Korkmaz, Goksuluk \& Zararsiz, 2014) and Psych (Revelle, 2018) packages.

\section{RESULTS}

The LOT were validated using the guidelines of the American Educational Research Association, American Psychological Association e National Council on Measurement in Education (AERA, APA, \& NCME, 2014).

\section{Confirmatory Factor Analysis}

The one-dimensional model results showed poor adjustments $\quad(\chi 2=115.51, \quad \mathrm{df}=9 ; \quad \mathrm{CFI}=0.787$; TLI=0.645; RMSEA=0.111 (90\% IC = 0.094-0.130); $\mathrm{SRMR}=0.086$ ). Despite the modifications made after analysing the factor and residual loading index, no improvement was achieved in the one-dimensional model. The results for model with two factors (Optimism and Pessimism) and six items showed a satisfactory adjustment $(\chi 2=4.541, \mathrm{df}=8 ; \mathrm{CFI}=1$; $\mathrm{TLI}=1 ; \quad \mathrm{RMSEA}=0 \quad(90 \% \mathrm{IC}=0.000-0.024)$; SRMR=0.016). The correlation between latent variables was -0.33 . So, Figure 1 shows the structure of the Brazilian version of the LOT-R-Sport with two factors and 6 items.

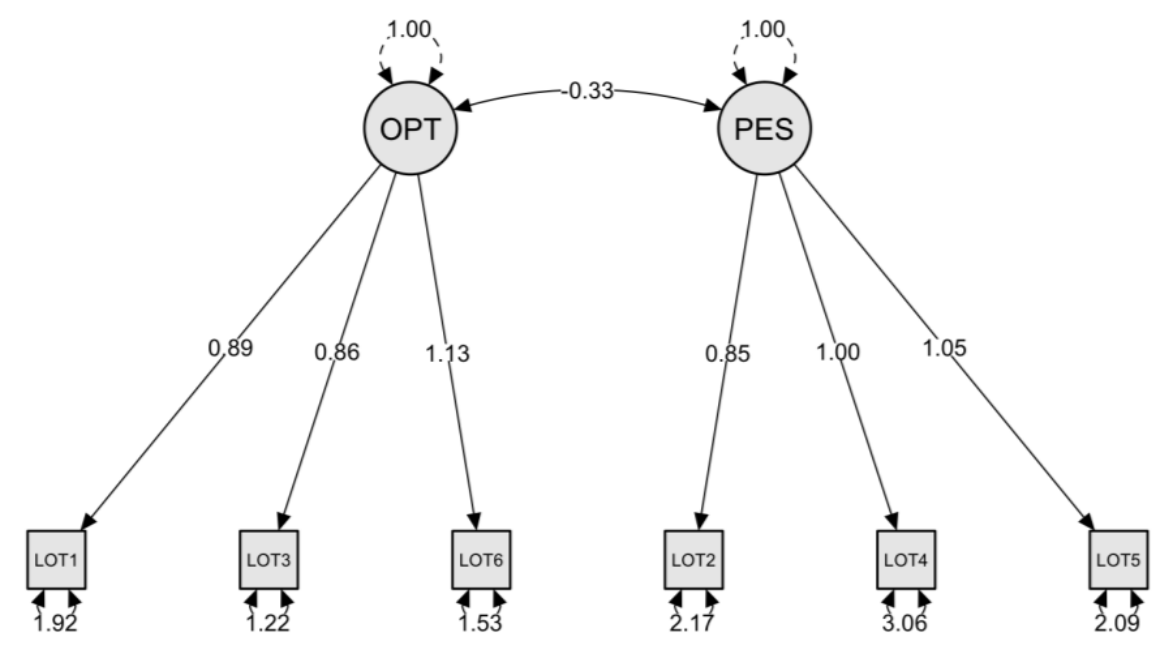

Figure 1. Structural model of the version of the LOT-R-Sport. Note: OPT = optimism; PES = pessimism

Regarding internal consistence, the composite reliability for Optimism was $\mathrm{CR}=0.72$, and for Pessimism was $\mathrm{CR}=0.70$. The standardized factor loadings of the LOT-R-Sport are presented in the table 1. 
Table 1.

Average values, standard deviation and factor loadings from the LOT-R-Sport

\begin{tabular}{lccc}
\hline Items LOT-R-Sport & M & SD & FL \\
\hline $\begin{array}{l}\text { 1. Durante as competições, tenho grandes expectativas, mesmo quando surgem situações } \\
\text { difíceis }\end{array}$ & 5.38 & 1.64 & .64 \\
2. Durante as competições, se alguma coisa pode dar errado comigo, com certeza vai dar & 2.54 & 1.70 & .70 \\
errado & 5.69 & 1.40 & .62 \\
3. Durante as competições sou otimista em relação aos meus resultados & 3.23 & 2.01 & .60 \\
4. Durante as competições, eu não acho que as coisas vão dar certo para mim & 3.70 & 1.79 & .69 \\
5. Durante as competições, não espero obter bons resultados & 5.19 & 1.68 & .78 \\
6. Durante as competições, eu acho que vou obter mais resultados bons do que ruins & &
\end{tabular}

Note: Optimism (items 1, 3 and 6) and Pessimism (items 2, 4 and 5); M=mean score; SD=standard deviation; FL= standardized factor loadings

In addition to the evidence of validity based on the internal structure, the evidence of validity based on the external measures was evaluated. Spearman's correlations between the LOT-R-Sport and SMS-II, BRS, and SWL were examined. It was expected that the positive variables would be positively correlated with optimist and negatively with pessimism whereas the negative variables would be positively correlated with pessimism and negatively with optimism. As it can be seen in Table 2, the optimism score showed higher correlations with resilience, motivation and satisfaction with life. Conversely, pessimism showed similar pattern of associations with non-motivation, indicating the convergent validity of the LOT-R-Sport (Table 2).

Table 2.

Correlations between the LOT-R-Sport and SWL, BRS and SMS-II scores

\begin{tabular}{lll}
\hline Construct (Scale) & Optimism & Pessimism \\
\hline Resilience (BRS) & $0.335^{* * *}$ & $-0.200^{* * *}$ \\
Satisfaction with Life (SWV) & $0.238^{* * *}$ & $-0.093^{* *}$ \\
Motivation Autonomous (SMS-II) & $0.241^{* * *}$ & -0.002 \\
Non Motivation (SMS-II) & $-0.144^{* * *}$ & $0.127^{* * *}$ \\
\hline
\end{tabular}

Note. Spearman correlations $* \mathrm{p}<.05, * * \mathrm{p}<.01, * * * \mathrm{p}<.001$

\section{Measurement Invariance of the LOT-R-Sport}

The unconstrained models presented good goodnessof-fit indexes, suggesting acceptability for the factor structure of LOT-R-Sport for girls and boys, team an individual sports, different ages and years of experience. The results of the model 2 showed the items were answered similarly (unbiased) between groups. The model 3 showed the intercepts were the

\section{Table 3.}

Test for invariance across gender, team and individual sports, age and years of experience of the LOT-R-Sport Brazilian version same for both groups. As it can be seen in Table 3, the three models presented excellent goodness-of-fit indexes, the LOT-R-Sport fit well in both sexes, both sports, all ages and years of experience indicating that the proposed structure remains stable. Comparisons between groups could be safely conducted since, metric and scalar invariance were achieved (Saris \& Satorra, 2018). 


\section{Psychometric Properties of the LOT-R for Sport}

\begin{tabular}{llllll}
\hline LOT-R-Sport & RMSEA (90\% IC) & SRMR & TLI & CFI & $\Delta$ CFI \\
\hline Gender & & & & & \\
Model 1. Configural & $.032(.000-.057)$ & .038 & .971 & .985 & \\
Model 2. Metric & $.034(.000-.073)$ & .039 & .970 & .984 & .001 \\
Model 3. Scalar & $.035(.000-.073)$ & .036 & .970 & .984 & .000 \\
Team and individual sports & & & & & \\
Model 1. Configural & $.001(.000-.042)$ & .029 & 1 & 1 & \\
Model 2. Metric & $.020(.000-.046)$ & .036 & .989 & .993 & .007 \\
Model 3. Scalar & $.010(.000-.039)$ & .032 & .997 & .998 & +.005 \\
Age & & & & & \\
Model 1. Configural & $.000(.000-.030)$ & .037 & 1 & 1 & \\
Model 2. Metric & $.000(.000-.016)$ & .042 & 1 & .999 & .001 \\
Model 3. Scalar & $.000(.000-.027)$ & .044 & 1 & .997 & .002 \\
Time experience & & & & & \\
Model 1. Configural & $.000(.000-.030)$ & .032 & 1 & 1 & \\
Model 2. Metric & $.023(.000-.049)$ & .045 & .986 & .990 & .010 \\
Model 3. Scalar & $.029(.000-.051)$ & .046 & .976 & .980 & .010 \\
\hline
\end{tabular}

Note. SRMR; standardized root mean square residual; RMSEA; root mean square of error of approximation; TLI: Tucker-Lewis index, CFI comparative fit index.

\section{DISCUSSION}

This study reported the procedures used to adapt and validate the LOT-R for the Brazilian sports context (LOT-R-Sport). The scale adaptation was used to provide items that significantly measure optimism in the sports context. Athletes and scholars in the field confirmed the relevance of the items. The reliability analysis also indicated that the items are adequate to assess optimism in the sports context. LOT-R-Sport has a clear structure with two related factors and has adequate psychometric properties.

In the original study, the authors designed items and developed the LOT-R as a one-dimensional scale to measure optimism. Some studies support the two-dimensional view of optimism and pessimism (Hinz et al., 2017), while others claim that the division is the result of the difference in the method used to answer the questions (Chiesi, Galli, Primi, Innocenti \& Bonacchi, 2013). Hinz et al. (2017) examined the psychometric properties of the LOT-R in 9.711 adults and confirmed the bidimensional structure of the scale. Study that validated the European Portuguese version for the general population, also found evidence of the two-factors of LOT-R (Ribeiro, Pedro \& Marques, 2012). Appaneal (2012) examined the factor structure of the scale with athletes and results of this study support the two-factor structure, which is consistent with accumulating evidence outside of sport and exercise science (Ortín et al., 2018). The question of dimensionality has important practical implications, for example, research has shown that the presence of pessimism, but not the absence of optimism, was a significant predictor of depressive symptoms (Jovanović \& Jerković, 2013). Thus, the authors of the LOT-R concluded that it must be the researcher's choice to separate the items into two groups or keep them as one factor, considering a better prediction of the results (Carver \& Scheier, 2014).

The LOT-R-Sport presented evidence of validity based on the internal structure (factorial structure, reliability, configural, metric and scalar invariance) and based on external measures. LOT-RSport was compared to other instruments that measure the psychological constructs associated with sports performance. Regarding SMS-II, it was expected that 


\section{Angelo et al.}

Autonomous Motivation would be positively correlated with the optimistic athlete while NonMotivation would be positively correlated with Pessimism. Optimism would be positively correlated with the SWL scale (Desrumaux, Lapointe, Ntsame, Boudrias, Savoie \& Brunet, 2015; Homaei, Bozorgi, Ghahfarokhi \& Hosseinpour, 2016) and with BRS. Satisfied with life and resilient people tend to expect positive and favourable results in their lives with a general expectation of success (Juarros et al., 2018; Vallarino \& García, 2019). The significant correlations between the positive variables corroborate these hypotheses.

Although athletes from different sports were involved in the analysis of the data, the study was limited to adolescent athletes aged between 15 and 17 years. The representativeness of the population was also limited to Brazilians residing in the state of São Paulo. Brazil is a country of continental dimensions with a great cultural variety and distinct customs and, although the majority of the population lives in large cities, the generalization of the results, both for other countries and for other Brazilian states, needs more empirical evidence.

The configural, metric and scalar invariance was achieved, indicating that LOT-R-Sport can measure constructions equally between boys and girls, team an individual sports, ages and years of experience. However, a natural extension of this study would be to test the invariance over age (for example, adolescents vs. adults), culture (southeast vs. northeast) and time (temporal stability). This would fill in the gaps in the LOT-R-Sport validation process. Once the measurement invariance is well established, researchers can claim that comparisons between groups come from real differences between groups and not because of the measurement bias within the instrument. Despite the limitations presented, the adaptation of LOT-R-Sport to the sporting context is the first step for future work on the influence of optimism in the Brazilian sporting context.

\section{PRACTICAL APPLICATIONS}

This study provides the results on the validity and invariance across sexes, sports, ages and years of experience of LOT-R for use in Brazilian athletes, providing to the scientific community a version adapted to the sport context of the instrument most used for the evaluation of optimism. The availability of a suitable instrument to measure adolescent athletes is the first step in understanding how psychological characteristics, such as optimism, are associated with performance. The identification of these characteristics can be very useful to stimulate the development of optimistic attitudes in adolescent athletes and, consequently, to improve the performance of these athletes.

\section{REFERENCES}

1. American Educational Research Association, American Psychological Association, \& National Council on Measurement in Education. (2014). Standards for educational and psychological testing. Washington, DC: American Psychological Association.

2. Appaneal, R. N. (2012). A Confirmatory factor analysis of the Life Orientation Test-Revised with competitive atthletes. Research Quarterly for Exercise and Sport, 83(4), 592-596. https://doi.org/10.1080/02701367.2012.1059988 5

3. Bagozzi, R., \& Yi, Y. (1988). On the evaluation of structural equation models. Journal of the Academy of Marketing Science, 16(2), 74-94. https://doi.org/10.1007/BF02723327

4. Bastianello, M. R., Pacico, J. C., \& Hutz, C. S. (2014). Optimism, self-esteem and personality: adaptation and validation of the Brazilian Version Of The Revised Life Orientation Test (LOT-R). Psico-USF, 19(3), 523-531. https://doi.org/10.1590/1413-827120140190030

5. Beaton, D., Bombardier, C., Guillemin, F., \& Ferraz, M. B. (2000). Guidelines for the Process of Cross-Cultural Adaptation of Self-Report Measures. Spine, 25(24), 3186-3191. https://doi.org/10.1097/00007632-20001215000014

6. Brown, T. (2015). Confirmatory factor analysis for applied research (2th ed.). Guilford Publications.

7. Carver, C., \& Scheier, M. (2014). Optimism. Trends in Cognitive Sciences, 18(6), 2-10. https://doi.org/10.1016/j.tics.2014.02.003

8. Cheung, G. W., \& Rensvold, R. B. (2002). Evaluating Goodness-of-Fit Indexes for Testing Measurement Invariance. Structural Equation 


\section{Psychometric Properties of the LOT-R for Sport}

Modeling: A Multidisciplinary Journal, 9(2), 233255. https://doi.org/10.1207/S15328007SEM0902_5

9. Chiesi, F., Galli, S., Primi, C., Innocenti P., \& Bonacchi, A. (2013). The accuracy of the Life Orientation Test-Revised (LOT-R) in measuring dispositional optimism: evidence from Item Response Theory Analyses. Journal of Personality Assessment, $\quad 95(2)$, 18-29. https://doi.org/10.1080/00223891.2013.781029

10. Desrumaux, P., Lapointe, D., Ntsame, M., Boudrias, J. S., Savoie, A., \& Brunet, L. (2015). The impact of job demands, climate, and optimism on well-being and distress at work: What are the mediating effects of basic psychological need satisfaction? Revue Europeenne de Psychologie Appliquee, 65(4), 179-188. https://doi.org/10.1016/j.erap.2015.06.003

11. Diener, E., Emmons, R., Larsen, R., \& Griffin, S. (1985). The Satisfaction With Life Scale. Journal of Personality Assessment, 49, 71-75. https://doi.org/10.1207/s15327752jpa4901_13

12. Epskamp, S. (2017). Package semPlot path diagrams and visual analysis of various SEM Packages' Output. doi:0.1561/2200000016>

13. García, C. R., Vallarino, V. T., \& Montero, F. J. O. (2014). Resiliencia, optimismo y burnout en judokas de competición Uruguayos. Revista Iberoamericana de Psicologia Del Ejercicio y El Deporte, 9(2), 271-286.

14. Gouveia, V. V., Milfont, T. L., da Fonseca, P. N., \& Coelho, J. M. (2009). Life Satisfaction in Brazil: Testing the Psychometric Properties of the Satisfaction With Life Scale (SWLS) in Five Brazilian Samples. Social Indicators Research, 90(2), 267-277. https://doi.org/10.1007/s11205008-9257-0

15. Hair, J. F., Babin, B. J., \& Krey, N. (2017). Covariance-Based Structural Equation Modeling in the Journal of Advertising: Review and Recommendations. Journal of Advertising, 46(1), 163-177. https://doi.org/10.1080/00913367.2017.1281777

16. Hinz, A., Sander, C., Glaesmer, H., Brähler, E., Zenger, M., Hilbert, A., \& Kocalevent, R. (2017). Optimism and pessimism in the general population: Psychometric properties of the Life Orientation Test (LOT-R). International Journal of Clinical and Health Psychology, 17(2), 161170. https://doi.org/10.1016/j.ijchp.2017.02.003
17. Hirschfeld, G., \& von Brachel, R. (2014). Multiple-Group confirmatory factor analyses in $\mathrm{R}$ -A tutorial in measurement invariance with continuous and ordinal data. Practical Assessment, Research and Evaluation, 19(7), 112.

18. Homaei, R., Bozorgi, Z. D., Ghahfarokhi, M. S. M., \& Hosseinpour, S. (2016). Relationship between Optimism, Religiosity and Self-Esteem with Marital Satisfaction and Life Satisfaction. International Education Studies, 9(6), 53-61. https://doi.org/10.5539/ies.v9n6p53

19. Jovanović, V., \& Jerković, V. (2013). Dimensionality and validity of the Serbian version of the Life Orientation Test-Revised in a Sample of Youths. Journal of Happiness Studies, 14(3), 771-782. https://doi.org/10.1007/s10902-0129354-2

20. Juarros, A., Valle, S., González, M., Rosado, B., \& Rosa, A. F. M. (2018). Relationship of internal training load, optimism and resilience with recovery-stress levels in swimmers. Cuadernos de Psicologia Del Deporte, 18(1), 43-54.

21. Korkmaz S., Goksuluk D., \& Zararsiz G. (2014). MVN: An R package for assessing multivariate normality. The $\mathrm{R}$ Journal, 6(2), 151-162. https://doi.org/10.32614/RJ-2014-031

22. Nascimento Junior, J. R. A., Vissoci, J. R. N., Balbim, G. M., Moreira, C. R., Pelletier, L., \& Vieira, L. F. (2014). Adaptação transcultural e análise das propriedades psicométricas da sport motivation scale-II no contexto Brasileiro. Revista Da Educação Física, 25(3), 441-458. https://doi.org/10.4025/reveducfis.v25i3.24855

23. Naveira, A., \& Morales, J. (2010). Relación entre optimism/ pesimismo disposicional, rendimiento y edad en jugadores de fútbol de competición. Revista Iberoamericana de Psicologia Del Ejercicio y El Deporte, 34(1), 153-161.

24. Neves, N., Barbosa, P., Silva, S., Brandão, M. R. F., \& Zanetti, M. C. (2018). Confirmatory factor analysis of the Brief Resilience Scale for Brazilian athletes. Cuadernos de Psicología Del Deporte, 18(1), 103-110.

25. Öcal, E., Aygar, H., Atay, E., Ozturk, G., Onsuz, M., \& Metintas, S. (2017). The relation of health related quality of life and optimism subdimension of life orientation test. European Journal of Public Health, 27(3), 2017-2018. https://doi.org/10.1093/eurpub/ckx186.243 


\section{Angelo et al.}

26. Ortín, F. J., Rodríguez, A., García, C., de los Fayos, E. J. G., \& González, J. (2018). Relación entre optimismo y rendimiento deportivo. Revision sistemática. Anales de Psicologia, 5(1), 45-60.

27. Pelletier, L. G., Rocchi, M. A., Vallerand, R. J., Deci, E. L., \& Ryan, R. M. (2013). Validation of the revised sport motivation scale (SMS-II). Psychology of Sport and Exercise, 14(3), 329341. https://doi.org/10.1016/j.psychsport.2012.12.002

28. R Core team. (2018). R: A language and environment for statistical computing. Vienna, Austria. Retrieved from https://www.rproject.org/

29. Ramírez, M., Holgado-Tello, F., Barbero García, M. I., \& Mendez, G. (2015). Confirmatory factor analysis: recommendations for unweighted least squares method related to Chi-Square and RMSEA Type I error. Accion Psicologica, 12(1), 79-90. https://doi.org/10.5944/ap.12.1.14362

30. Reche, C., Tutte, V. y Ortín, F. J. (2014). Resiliencia, optimismo y burnout en judokas de competición uruguayos. Revista Iberoamericana dePpsicología del Ejercicio y el Deporte, 9(2), 271-286.

31. Revelle, W. (2018). Psych: procedures for personality and psychological research, Northwestern University, Evanston, Illinois, USA, https://CRAN.Rproject.org/package $=$ psych Version $=1.8 .4$.

32. Ribeiro, J., Pedro, L., \& Marques, S. (2012). Dispositional optimism is unidimensional or bidimensional? The Portuguese Revised Life Orientation Test. The Spanish Journal of Psychology, 15(3), 1259-1271.
https://doi.org/10.5209/rev_SJOP.2012.v15.n3.3 9412

33. Rosseel, Y. (2012). lavaan: An R Package for Structural Equation. Journal of Statistical Software, 48(2), 1-36. https://doi.org/10.18637/jss.v048.i02

34. Saris, W., \& Satorra, A. (2018). The pooled data approach for the estimation of Split-Ballot multitrait. Structural Equation Modeling A Multidisciplinary Journal, 25(5), 659-672. https://doi.org/10.1080/10705511.2018.1431543

35. Scheier, M. F., \& Carver, C. S. (1985). Optimism, coping, and health: Assessment and implications of generalized outcome expectancies. Health Psychology, 4, 219-247. https://doi.org/10.1037/0278-6133.4.3.219

36. Scheier, M. F., Carver, C. S., \& Bridges, M. W. (1994). Distinguishing optimism from neuroticism (and trait anxiety, self-mastery, and self-esteem): A reevaluation of the Life Orientation Test. Journal of Personality and Social Psychology, 67(6), 1063-1078. https://doi:10.1037/0022-3514.67.6.1063

37. Smith, B. W., Dalen, J., Wiggins, K., Tooley, E., Christopher, P., \& Bernard, J. (2008). The brief resilience scale: assessing the ability to bounce back. International Journal of Behavioral Medicine, 15(3), 194- 200. 44.

38. Vallarino, T., \& García, R. (2019). Burnout, resilience and optimism female hockey. Cuadernos de Psicologia Del Deporte, 16(3), 7378.

39. Wickham. H. (2017). Tidyverse: easily install and load the 'tidyverse'. R package version 1.2.1. https://CRAN.R-project.org/package=tidyversre. 